\title{
VEGETATIVE PROPAGATION OF Bauhinia $x$ blakeana, AN ORNAMENTAL STERILE TREE ${ }^{1}$
}

Renata Bachin Mazzini ${ }^{2}$, Kathia Fernandes Lopes Pivetta ${ }^{3}$, Gustavo de Nobrega Romani² e Breno Furlan Bueno 4

\begin{abstract}
Bauhinia $\mathrm{x}$ blakeana (B. purpurea $\mathrm{x}$ B. variegata) is a natural hybrid that has been cultivated in gardens, streets and parks. Due to its sterility, it must be vegetatively propagated. The objective of this work was to evaluate the viability of cuttings and grafting on its propagation. Semi-woody cuttings were collected during four seasons and treated with 0;1,000; 2,000; and 3,000 $\mathrm{mg} \mathrm{L}^{-1}$ of IBA. The experimental design was entirely randomized and the treatments were arranged in a $4 \times 4$ factorial scheme (four collecting times $\mathrm{x}$ four IBA concentrations) and five replications with 10 cuttings each, per collecting time and per IBA concentration. Characteristics of roots and shoots were evaluated after 90 days. The data means were compared by the Tukey test and submitted to the polynomial regression analysis. For the grafting experiment, $B$. variegata and $B$. variegata var. candida plants of six and 12 months were used as rootstocks and the splice graft and T-budding methods were tested. The experimental design was entirely randomized and the treatments were arranged in a $2 \times 2 \times 2$ factorial scheme (two rootstock species $\mathrm{x}$ two grafting methods $\mathrm{x}$ two rootstock ages) and four replications with five plants each, per rootstock species, per grafting method and per rootstock age. Characteristics of shoots were evaluated after 90 days and the data means were compared by the Tukey test. B. x blakeana can be propagated by semi-woody cuttings collected in spring, without IBA application, or in summer, with the application of 3,000 $\mathrm{mg} \mathrm{L}^{-1}$ of IBA. The tested grafting methods were not effective.
\end{abstract}

Keywords: Cuttings, Indolebutyric acid, Collecting time.

\section{PROPAGAÇÃO VEGETATIVA DE Bauhinia x blakeana, UMA ARBÓREA ORNAMENTAL ESTÉRIL}

\begin{abstract}
RESUMO-Bauhinia x blakeana (B. purpurea $x$ B. variegata) é um híbrido natural que tem sido cultivado em jardins, ruas e parques. Por ser estéril, é essencial que seja multiplicado vegetativamente. O objetivo deste trabalho foi verificar a viabilidade da estaquia e da enxertia na propagação desse híbrido. Estacas semilenhosas foram coletadas nas quatro estações do ano e tratadas com 0, 1.000, 2.000 e $3.000 \mathrm{mg} \mathrm{L}^{-1}$ de AIB. O delineamento foi inteiramente casualizado, e os tratamentos foram arranjados em esquema fatorial duplo (quatro estações do ano x quatro concentrações de AIB) e cinco repetições com 10 estacas cada, por concentração de AIB e por estação do ano. Características vegetais e radiculares das estacas foram avaliadas após 90 dias. As médias dos dados foram comparadas pelo teste de Tukey e submetidas à análise de regressão polinomial. Para a enxertia, mudas de seis e 12 meses de B. variegata e B. variegata var. candida foram usadas como porta-enxerto, e os métodos de garfagem inglês simples e borbulhia "T" invertido foram testados. O delineamento foi inteiramente casualizado, e os tratamentos foram arranjados em esquema fatorial triplo (duas espécies de porta-enxerto $x$ dois tipos de enxertia $x$ duas idades do porta-enxerto) e quatro repetições
\end{abstract}

\footnotetext{
${ }^{1}$ Recebido em 06.05.2012 e aceito para publicação em 09.04.2013.

${ }^{2}$ Programa de Pós-Graduação em Agronomia (Produção Vegetal), Faculdade de Ciências Agrárias e Veterinárias, UNESP, Universidade Estadual Paulista, Brasil. E-mail:<remazzini@yahoo.com.br $>$ e $<$ gustavonromani@yahoo.com.br $>$.

${ }^{3}$ Faculdade de Ciências Agrárias e Veterinárias, UNESP, Universidade Estadual Paulista, Departamento de Produção Vegetal, Brasil. E-mail:<kathia@fcav.unesp.br>.

${ }^{4}$ Graduação em Ciências Biológicas, Faculdade de Ciências Agrárias e Veterinárias, UNESP, Universidade Estadual Paulista, Brasil. E-mail:<brenofurlanbueno@yahoo.com.br>.
} 
com cinco mudas cada, por tipo de enxertia, por idade do porta-enxerto e por espécie. Características vegetais do enxerto foram avaliadas após 90 dias e as médias dos dados, comparadas pelo teste de Tukey. O híbrido B. x blakeana pode ser multiplicado por estacas semilenhosas coletadas na primavera, sem o uso de AIB, ou no verão, com a aplicação de $3.000 \mathrm{mg} \mathrm{L}^{-1}$ de AIB. Os métodos testados de enxertia não foram eficientes.

Palavras-chave: Estaquia, Ácido indolbutírico, Época de coleta.

\section{INTRODUCTION}

Bauhinia x blakeana Dunn belongs to the Fabaceae family and is a natural hybrid derived from the cross between $B$. purpurea L. and $B$. variegata L. This ornamental tree has been much cultivated in gardens, streets and parks of subtropical and temperate regions (LAU et al., 2005), showing easy adaptation (MAK et al., 2008). It is deciduous and produces dark pink fragrant flowers, which are the symbol of its original habitat, the Island of Hong Kong, in China (LAU et al., 2005; MAK et al., 2008).

According to Lau et al. (2005), this hybrid is completely sterile, as different fertilization methods originated no seeds. The authors also believe that $B$. $\mathrm{x}$ blakeana individuals are short-lived, lasting around 50 years, and that there is no evidence that this species is able to self propagate. Therefore, in order to preserve the species, it is essential to artificially propagate it. Cuttings or grafting on rootstocks of same genus species are the most indicated propagation methods (LAU et al., 2005; MAK et al., 2008).

Both methods have been frequently used for the multiplication of species that either produce low viability seeds or that do not produce them at all (AMRI et al., 2010), but also for the maintenance of the genetic characteristics of the mother plant, improvement of the seedling uniformity, suppression of the juvenile plant stage and combination of high quality clones, achieved in the latter case through grafting (HARTMANN et al., 2002; VALMORBIDA et al., 2008). However, there are more studies on cuttings than on grafting (ASAAH et al., 2011).

The cuttings technique is considered effective, fast and cheap (BAUL et al., 2011). However, there are some intrinsic and extrinsic factors that may influence cutting survival, such as mother plant age, cutting collecting time, cutting extraction areas from the mother plant, use of growth regulators (BHARDWAJ; MISHRA, 2005) and substrate types. Furthermore, the specific genetic configuration seems to be determinant for the rooting process of some species and even clones, as some of them can hardly be induced to root production (NEVES et al., 2006; NOUAIM et al., 2002).

There are various substrates that could be used for cuttings, such as sand, rice husks, soil, humus, vermiculite, coir and the mixture of them (LONE et al., 2010; LUZ et al., 2007). In general, the vermiculite has promoted good survival rates and growth characteristics for several species (ALTHAUS et al., 2007; PACHECO; FRANCO, 2008; ROBERTO et al., 2004). A substrate indication for the vegetative propagation of $B$. x blakeana was not found.

Among the growth regulators, the auxins show the greatest positive effects on the formation of adventitious roots (NICOLOSO et al., 1999). The indolebutyric acid (IBA) is probably the best auxin option for general use, as it has been very effective on promoting root growth from cuttings of a great range of species (HARTMANN et al., 2002). The ideal concentration varies according to each species, as high IBA levels may be toxic and cause the cutting death instead of positively acting on the root number and growth (BAUL et al., 2010).

The aim of this work was to evaluate the viability and effectiveness of the vegetative propagation of the sterile hybrid $B$. x blakeana through two methods: semi-woody cuttings collected in the four seasons and submitted to different IBA concentrations; and two types of grafting, splice graft and T-budding, using $B$. variegata and $B$. variegata var. candida (Aiton) Voigt. as rootstocks.

\section{MATERIALS AND METHODS}

Cuttings, grafts and buds were collected from $B$. $\mathrm{x}$ blakeana trees of about 20 years cultivated at the College of Agricultural and Veterinary Sciences of the State University of São Paulo (FCAV/UNESP), campus in Jaboticabal, Brazil. The campus is located at $21^{\circ} 15^{\prime} 22^{\prime \prime}$ $\mathrm{S}$ and $48^{\circ} 18^{\prime} 58^{\prime \prime} \mathrm{W}, 590 \mathrm{~m}$ of altitude. According to the Köppen classification, the climate regime in Jaboticabal 
is subtropical with dry winters and humid summers (Cwa). The cuttings and grafting experiments were carried out at the Experimental Nursery of Ornamental and Forest Plants of the FCAV/UNESP.

\subsection{Cuttings}

Semi-woody cuttings were collected from one-year old stems, located in the lower canopy portion, during the four seasons: August 2009 (winter), November 2009 (spring), February 2010 (summer) and May 2010 (autumn). The stems were cut into $15 \mathrm{~cm}$ length segments, early in the morning, leaving half of the two most upper leaves. As $B$. x blakeana is a deciduous tree, the winter cuttings did not have leaves. The bases of the cuttings were bevel cut and immediately immersed (around $1.5 \mathrm{~cm}$ of the bottom) in a 50\% IBA alcoholic solution of three concentrations $\left(1,000 ; 2,000\right.$; and 3,000 $\left.\mathrm{mg} \mathrm{L}^{-1}\right)$ for 10 seconds and then placed in plastic tubes for rooting, with around $2 / 3$ of their length deepened in the medium texture vermiculite substrate. The control treatment was the same $50 \%$ alcoholic solution without IBA $\left(0 \mathrm{mg} \mathrm{L}^{-1}\right)$.

The tubes were kept in a translucent plastic coated greenhouse under an intermittent misting system, which remained on for 10 minutes per hour, so that the cuttings and substrate were kept moistened. The temperature inside the greenhouse was daily monitored and the mean temperature for each rooting period were: $24.4{ }^{\circ} \mathrm{C}$ for winter, $29.4{ }^{\circ} \mathrm{C}$ for spring, $25.8^{\circ} \mathrm{C}$ for summer and $25.1^{\circ} \mathrm{C}$ for autumn. After 90 days, the following variables were evaluated: cutting survival and rooting, callus formation, leaf retention, number and dry matter of new leaves per cutting and number, length and dry matter of roots per cutting. The following relations were also calculated: number of new leaves per dry matter of new leaves (NL/DML), number of roots per length of roots (NR/ $\mathrm{LR})$, number of roots per dry matter of roots (NR/DMR) and length of roots per dry matter of roots (LR/DMR).

The experimental design was entirely randomized and the treatments were arranged in a $4 \times 4$ factorial scheme (four collecting times $\mathrm{x}$ four IBA concentrations) and five replications with 10 cuttings each, per collecting time and per IBA concentration, resulting in 800 cuttings. Data of percentage were transformed into arcsine $(\mathrm{x} / 100)^{1 / 2}$ and of number of new leaves into $\mathrm{x}^{1 / 2}+1$. Data means were then compared by the Tukey test at $5 \%$ of significance level and submitted to the polynomial regression analysis.

\subsection{Grafting}

Seeds of B. variegata and B. variegata var. candida were harvested from trees cultivated at the FCAV/UNESP campus in September 2009 and sowed in the Plantmax substrate, from Eucatex ${ }^{\circledR}$. After 20 days of sowing, seedlings were transplanted to $2 \mathrm{~L}$ plastic bags containing soil and cattle manure in a 3:1 ratio. The substrate analysis was then performed according to Raij et al. (2001) at the Laboratory of Soil Analysis of the FCAV/UNESP (data not shown) and as it was considered appropriate, there was no additional fertilization throughout the experiment.

Plants of B. variegata and B. variegata var. candida were used as rootstocks when they were six and 12 months old (March and September 2010, respectively) with a stem diameter of 6-8 $\mathrm{mm}$. Two grafting methods were tested: splice graft and T-budding. The splice graft was performed at around $13 \mathrm{~cm}$ above the soil level and the T-budding at around $8 \mathrm{~cm}$. The grafting area was wrapped with a plastic tape in order to keep moisture and, for the splice grafting, the plants were also covered with a translucent plastic bag. Plants were then maintained under half-shade at natural conditions, with a mean temperature of $22.8^{\circ} \mathrm{C}$ and air humidity above $70 \%$. After 20 days of grafting, the rootstocks were pruned at $1 \mathrm{~cm}$ above budding, as described by Carvalho et al. (2005). After 10 days of pruning, the plastic tape and bags were removed.

After 90 days of grafting, graft survival and the length and dry matter of shoots were evaluated.

The experimental design was entirely randomized and the treatments were arranged in a $2 \times 2 \times 2$ factorial scheme (two rootstock species $\mathrm{x}$ two grafting methods $\mathrm{x}$ two rootstock ages) and four replications with five plants each, per rootstock species, per grafting method and per rootstock age, resulting in 160 plants. Data means were compared by the Tukey test at $5 \%$ of significance level.

\section{RESULTS}

\subsection{Cuttings}

B. x blakeana cuttings collected in autumn and winter showed survival, rooting and callus formation rates close to null (data not shown) regardless the IBA concentration, so both collecting times were not statistically analyzed. Furthermore, even when the cuttings

Revista Árvore, Viçosa-MG, v.37, n.2, p.219-229, 2013 
survived, they did not produce roots. On the other hand, cuttings collected in spring and summer showed considerable survival and rooting rates (Table 1), with spring values much higher than the summer ones. In fact, all cuttings that survived also produced roots; thus, they had similar values for both variables, so only the rooting rate was statistically analyzed. Furthermore, the callus formation variable also showed similar results, with summer values a little higher than the summer rooting ones. The callus formation results found in spring were similar to the survival and rooting rates.

Cuttings collected in spring showed higher leaf retention rate than the summer ones and also produced more leaves (Table 2), but the NL/DML relation generated statistically similar results from both spring and summer cuttings (data not shown). The same was observed for rooting, that is, spring cuttings produced more roots, which were longer with more matter, and also showed better results of the NR/LR and NR/DMR relations (Table 3 ). With respect to the LR/DMR relation, summer cuttings reached higher values and differed from the spring ones.

The interaction among the collecting seasons and IBA concentrations was significant for leaf retention, root length and root dry matter (Tables 2 and 3 ). The data from the collecting seasons were significant for all variables, except for the NL/DML relation (data not shown). The results from the IBA concentrations were only significant for leaf retention, root dry matter and the LR/DMR relation.

The polynomial regression analysis for the spring cuttings indicated that there was a significant difference only for leaf retention, root number and root dry matter, which decreased as the IBA concentration increased (Figure 1). For the summer cuttings, there was a significant difference for rooting, callus formation and root length, which increased as the IBA concentration also increased. For the variable LR/DMR relation, which was also significant, the regression had a quadratic adjustment and the maximum value was obtained for the IBA concentration of 2,000 $\mathrm{mg} \mathrm{L}^{-1}$ (Figure 2).

\subsection{Grafting}

The grafting experiment resulted in very low or null rates of graft survival regardless the rootstock species, grafting method and rootstock age (data not shown), so that the statistical analysis was not performed. Furthermore, not all of the grafts or buds that were alive sprouted.

Table 1 - Rooting and callus formation of Bauhinia $\mathrm{x}$ blakeana cuttings collected in the spring and summer and submitted to different IBA concentrations.

Tabela 1 - Enraizamento e formação de calos em estacas de Bauhinia x blakeana coletadas na primavera e no verão e submetidas a diferentes concentrações de AIB.

\begin{tabular}{|c|c|c|c|}
\hline \multicolumn{4}{|c|}{ Rooting $(\%)^{1}$} \\
\hline \multirow{2}{*}{ IBA Concentration $\left(\mathrm{mg} \mathrm{L}^{-1}\right)$} & \multicolumn{2}{|c|}{ Collecting Season } & \multirow{2}{*}{ IBA Concentration Means } \\
\hline & Spring(2009) & Summer(2010) & \\
\hline 0 & 69.50 & 20.52 & $45.01 \mathrm{a}$ \\
\hline 1,000 & 59.51 & 26.29 & $42.89 \mathrm{a}$ \\
\hline 2,000 & 45.00 & 24.57 & $34.79 \mathrm{a}$ \\
\hline 3,000 & 57.55 & 28.81 & $43.18 \mathrm{a}$ \\
\hline Collecting Season Means & $57.89 \mathrm{~A}$ & $25.04 \mathrm{~B}$ & \\
\hline \multirow{3}{*}{ IBA Concentration $\left(\mathrm{mg} \mathrm{L}^{-1}\right)$} & \multicolumn{2}{|c|}{ Callus Formation $(\%)^{1}$} & \multirow{3}{*}{ IBA Concentration Means } \\
\hline & \multicolumn{2}{|c|}{ Collecting Season } & \\
\hline & Spring & Summer & \\
\hline 0 & 69.50 & 22.56 & $46.03 \mathrm{a}$ \\
\hline 1,000 & 59.51 & 26.27 & $42.89 \mathrm{a}$ \\
\hline 2,000 & 45.00 & 24.57 & $34.79 \mathrm{a}$ \\
\hline 3,000 & 57.55 & 28.81 & $43.18 \mathrm{a}$ \\
\hline Collecting Season Means & $57.89 \mathrm{~A}$ & $25.55 \mathrm{~B}$ & \\
\hline
\end{tabular}

${ }^{1}$ Data transformed into arcsine $(\mathrm{x} / 100)^{1 / 2}$

Means followed by different upper case letters in the lines differ from each other for the collecting seasons by the Tukey test at $5 \%$ of significance level. Means followed by the same lower case letters in the columns do not differ from each other for the IBA concentrations by the Tukey test at $5 \%$ of significance level. Means that are not followed by letters show no significant interaction among the treatments.

Revista Árvore, Viçosa-MG, v.37, n.2, p.219-229, 2013 
Table 2 - Leaf retention, number of leaves and dry matter of leaves of Bauhinia x blakeana cuttings collected in the spring and summer and submitted to different IBA concentrations.

Tabela 2 - Retenção foliar, número de folhas e matéria seca de folhas em estacas de Bauhinia x blakeana coletadas na primavera e no verão e submetidas a diferentes concentrações de AIB.

\begin{tabular}{|c|c|c|c|}
\hline \multicolumn{4}{|c|}{ Rooting $(\%)^{1}$} \\
\hline \multirow{2}{*}{ IBA Concentration $\left(\mathrm{mg} \mathrm{L}^{-1}\right)$} & \multicolumn{2}{|c|}{ Collecting Season } & \multirow{2}{*}{ IBA Concentration Means } \\
\hline & Spring(2009) & Summer(2010) & \\
\hline 0 & 67.79 Аа & $21.24 \mathrm{Ba}$ & $44.51 \mathrm{a}$ \\
\hline 1,000 & $56.05 \mathrm{Aab}$ & $29.96 \mathrm{Ba}$ & $43.00 \mathrm{ab}$ \\
\hline 2,000 & $34.94 \mathrm{Ac}$ & $22.56 \mathrm{Aa}$ & $28.75 \mathrm{~b}$ \\
\hline 3,000 & $45.00 \mathrm{Abc}$ & $29.96 \mathrm{Aa}$ & $37.48 \mathrm{ab}$ \\
\hline Collecting Season Means & $50.94 \mathrm{~A}$ & $25.93 \mathrm{~B}$ & \\
\hline \multirow{4}{*}{ IBA Concentration $\left(\mathrm{mg} \mathrm{L}^{-1}\right)$} & \multirow{3}{*}{\multicolumn{2}{|c|}{$\begin{array}{l}\text { Number of Leaves }{ }^{2} \\
\text { Callus Formation }(\%)^{1} \\
\text { Collecting Season }\end{array}$}} & \multirow{4}{*}{ IBA Concentration Means } \\
\hline & & & \\
\hline & & & \\
\hline & Spring & Summer & \\
\hline 0 & 1.35 & 1.18 & $1.27 \mathrm{a}$ \\
\hline 1,000 & 1.41 & 1.10 & $1.25 \mathrm{a}$ \\
\hline 2,000 & 1.48 & 1.23 & $1.35 \mathrm{a}$ \\
\hline 3,000 & 1.45 & 1.13 & $1.29 \mathrm{a}$ \\
\hline Collecting Season Means & $1.42 \mathrm{~A}$ & $1.16 \mathrm{~B}$ & \\
\hline \multirow{3}{*}{ IBA Concentration $\left(\mathrm{mg} \mathrm{L}^{-1}\right)$} & \multirow{2}{*}{\multicolumn{2}{|c|}{$\begin{array}{c}\text { Dry Matter of Leaves }(\mathrm{g}) \\
\text { Collecting Season }\end{array}$}} & \multirow{3}{*}{ IBA Concentration Means } \\
\hline & & & \\
\hline & Spring & Summer & \\
\hline 0 & 0.12 & 0.08 & $0.10 \mathrm{a}$ \\
\hline 1,000 & 0.17 & 0.03 & $0.10 \mathrm{a}$ \\
\hline 2,000 & 0.12 & 0.04 & $0.08 \mathrm{a}$ \\
\hline 3,000 & 0.20 & 0.06 & $0.13 \mathrm{a}$ \\
\hline Collecting Season Means & $0.15 \mathrm{~A}$ & $0.07 \mathrm{~B}$ & \\
\hline
\end{tabular}

${ }^{1}$ Data transformed into arcsine $(\mathrm{x} / 100)^{1 / 2}$.

Means followed by different upper case letters in the lines differ from each other for the collecting seasons by the Tukey test at $5 \%$ of significance level. Means followed by the same lower case letters in the columns do not differ from each other for the IBA concentrations by the Tukey test at $5 \%$ of significance level. Means that are not followed by letters show no significant interaction among the treatments.

\section{DISCUSSION}

\subsection{Cuttings}

The low survival and rooting rates found in the cuttings collected in autumn and winter may be influenced by several factors. The collecting season, for instance, is determinant on the cuttings ability of survival and rooting (NEVES et al., 2006; NOUAIM et al., 2002). The species that originated $B . \mathrm{x}$ blakeana and the hybrid itself are deciduous plants, so they lose their leaves during winter that, in the Southern Hemisphere, happens from June to September. These plants then restart their vegetative growth at the end of this period which, according to Hartmann et al. (2002), would be the ideal time for the cuttings of deciduous species. However, the rooting ability of each species may be related to its own genetic configuration ( $\mathrm{SHI}$; BREWBAKER, 2006) that varies according to the species. Neves et al. (2006), for instance, did not detect rooting of semi-woody cuttings of Erythrina falcata Benth. regardless the collecting time.

The $B . \mathrm{x}$ blakeana vegetative resting period, which happens in winter, is immediately preceded by its flowering that happens in autumn. Therefore, the nutrient accumulation in the cuttings might have been insufficient for the production of roots or new leaves, what would explain the low survival and rooting rates of cuttings collected during both the winter and autumn periods.

The absence of leaves on the winter cuttings may also have influenced their low survival, as they were not able to start the production of photo-assimilated 
Table 3 - Number of roots (NR), length of roots (LR), dry matter of roots (DMR) and the relations among those variables of Bauhinia $\mathrm{x}$ blakeana cuttings collected in the spring and summer and submitted to different IBA concentrations.

Tabela 3 - Número de raízes $(N R)$, comprimento de raízes $(L R)$, matéria seca de raízes $(D M R)$ e relações entre essas variáveis em estacas de Bauhinia x blakeana coletadas na primavera e no verão e submetidas a diferentes concentrações de AIB.

\begin{tabular}{|c|c|c|c|}
\hline \multicolumn{4}{|c|}{ Number of Roots } \\
\hline \multirow{2}{*}{ IBA Concentration $\left(\mathrm{mg} \mathrm{L}^{-1}\right)$} & \multicolumn{2}{|c|}{ Collecting Season } & \multirow{2}{*}{ IBA Concentration Means } \\
\hline & Spring(2009) & Summer(2010) & \\
\hline 0 & 23.76 & 2.30 & $13.03 \mathrm{a}$ \\
\hline 1,000 & 22.06 & 2.32 & $12.19 \mathrm{a}$ \\
\hline 2,000 & 13.70 & 2.18 & $7.94 \mathrm{a}$ \\
\hline 3,000 & 15.78 & 2.82 & $9.30 \mathrm{a}$ \\
\hline Collecting Season Means & $18.83 \mathrm{~A}$ & $2.41 \mathrm{~B}$ & \\
\hline \multirow{3}{*}{ IBA Concentration $\left(\mathrm{mg} \mathrm{L}^{-1}\right)$} & \multicolumn{2}{|c|}{ Length of Roots $(\mathrm{cm})$} & \multirow{3}{*}{ IBA Concentration Means } \\
\hline & \multicolumn{2}{|c|}{ Collecting Season } & \\
\hline & Spring & Summer & \\
\hline 0 & $9.10 \mathrm{Aa}$ & $1.42 \mathrm{Ba}$ & $5.26 \mathrm{a}$ \\
\hline 1,000 & $8.16 \mathrm{Aa}$ & $2.06 \mathrm{Ba}$ & $5.11 \mathrm{a}$ \\
\hline 2,000 & $4.96 \mathrm{Ab}$ & $2.07 \mathrm{Ba}$ & $3.51 \mathrm{a}$ \\
\hline 3,000 & $6.98 \mathrm{Aab}$ & $2.47 \mathrm{Ba}$ & $4.72 \mathrm{a}$ \\
\hline Collecting Season Means & $7.30 \mathrm{~A}$ & $2.01 \mathrm{~B}$ & \\
\hline \multirow{3}{*}{ IBA Concentration $\left(\mathrm{mg} \mathrm{L}^{-1}\right)$} & \multirow{2}{*}{\multicolumn{2}{|c|}{$\begin{array}{l}\text { Dry Matter of Leaves (g) } \\
\text { Collecting Season }\end{array}$}} & \multirow{3}{*}{ IBA Concentration Means } \\
\hline & & & \\
\hline & Spring & Summer & \\
\hline 0 & $0.39 \mathrm{Aa}$ & $0.06 \mathrm{Ba}$ & $0.23 \mathrm{a}$ \\
\hline 1,000 & $0.34 \mathrm{Aa}$ & $0.05 \mathrm{Ba}$ & $0.20 \mathrm{ab}$ \\
\hline 2,000 & $0.15 \mathrm{Ab}$ & $0.05 \mathrm{Aa}$ & $0.10 \mathrm{~b}$ \\
\hline 3,000 & $0.29 \mathrm{Aab}$ & $0.07 \mathrm{Ba}$ & $0.18 \mathrm{ab}$ \\
\hline Collecting Season Means & $0.29 \mathrm{~A}$ & $0.06 \mathrm{~B}$ & \\
\hline
\end{tabular}

\begin{tabular}{|c|c|c|c|}
\hline \multirow{3}{*}{ IBA Concentration $\left(\mathrm{mg} \mathrm{L}^{-1}\right)$} & \multicolumn{2}{|c|}{ NR/LR } & \multirow{3}{*}{ IBA Concentration Means } \\
\hline & \multicolumn{2}{|c|}{ Collecting Season } & \\
\hline & Spring & Summer & \\
\hline 0 & 2.63 & 1.53 & $2.08 \mathrm{a}$ \\
\hline 1,000 & 2.65 & 1.15 & $1.90 \mathrm{a}$ \\
\hline 2,000 & 2.65 & 1.03 & $1.84 \mathrm{a}$ \\
\hline 3,000 & 2.34 & 1.19 & $1.76 \mathrm{a}$ \\
\hline Collecting Season Means & $2.57 \mathrm{~A}$ & $1.22 \mathrm{~B}$ & \\
\hline \multirow{3}{*}{ IBA Concentration $\left(\mathrm{mg} \mathrm{L}^{-1}\right)$} & & & \multirow{3}{*}{ IBA Concentration Means } \\
\hline & & & \\
\hline & Spring & Summer & \\
\hline 0 & 62.05 & 34.45 & $48.25 \mathrm{a}$ \\
\hline 1,000 & 63.30 & 47.56 & $55.43 \mathrm{a}$ \\
\hline 2,000 & 86.91 & 46.46 & $66.69 \mathrm{a}$ \\
\hline 3,000 & 66.57 & 44.37 & $55.47 \mathrm{a}$ \\
\hline Collecting Season Means & $69.71 \mathrm{~A}$ & $43.21 \mathrm{~B}$ & \\
\hline \multirow{3}{*}{ IBA Concentration $\left(\mathrm{mg} \mathrm{L}^{-1}\right)$} & & & \multirow{3}{*}{ IBA Concentration Means } \\
\hline & \multicolumn{2}{|c|}{ Collecting Season } & \\
\hline & Spring & Summer & \\
\hline 0 & 23.52 & 23.32 & $23.42 \mathrm{~b}$ \\
\hline 1,000 & 24.12 & 43.24 & $33.68 \mathrm{ab}$ \\
\hline 2,000 & 36.18 & 48.61 & $42.39 \mathrm{a}$ \\
\hline 3,000 & 28.06 & 36.99 & $32.53 \mathrm{ab}$ \\
\hline Collecting Season Means & $27.97 \mathrm{~B}$ & $38.04 \mathrm{~A}$ & \\
\hline
\end{tabular}

Means followed by the same upper case letters in the lines do not differ from each other for the collecting seasons by the Tukey test at $5 \%$ of significance level. Means followed by the same lower case letters in the columns do not differ from each other for the IBA concentrations by the Tukey test at $5 \%$ of significance level. Means that are not followed by letters show no significant interaction among the treatments.

Revista Árvore, Viçosa-MG, v.37, n.2, p.219-229, 2013 

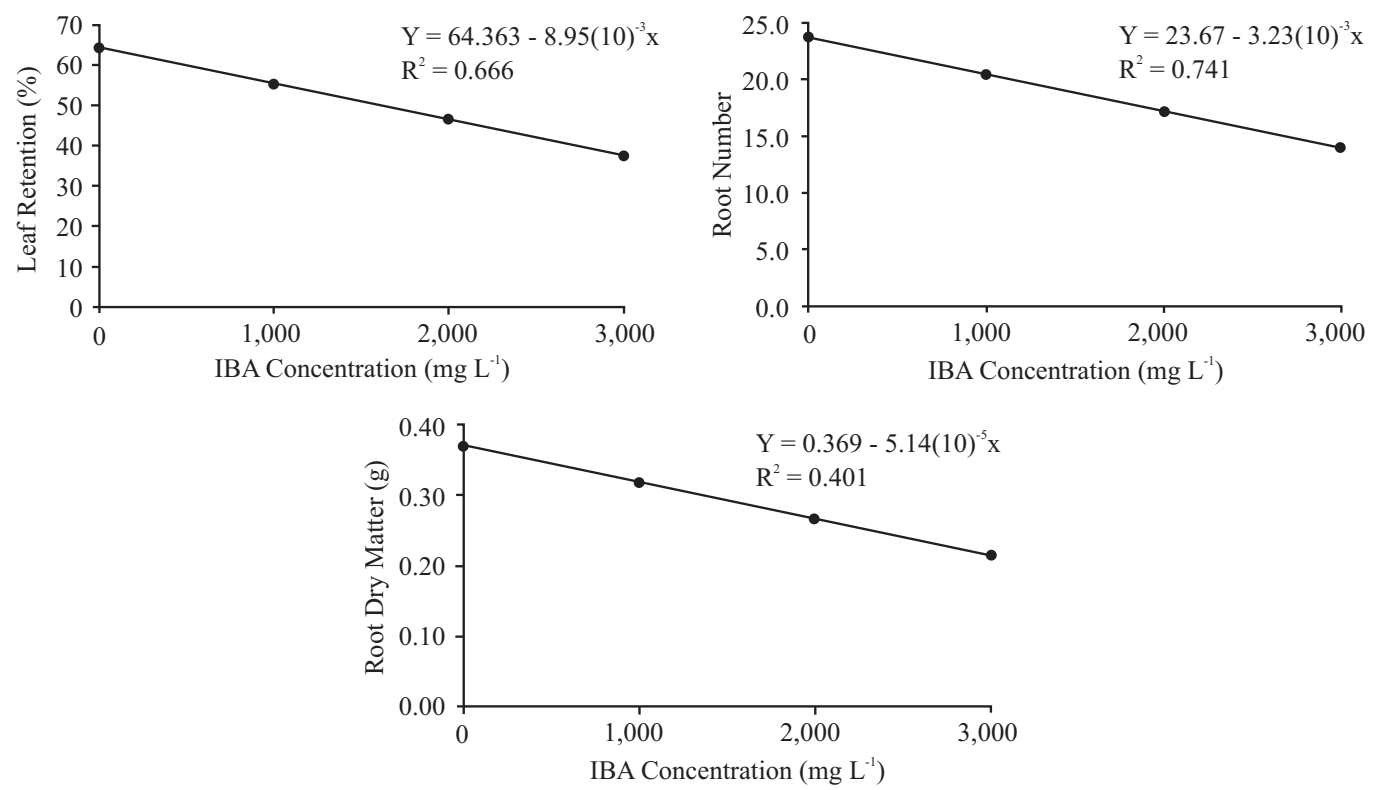

Figure 1 - Variations of leaf retention, root number and root dry matter of Bauhinia $\mathrm{x}$ blakeana cuttings collected in spring according to different IB A concentrations (2009).

Figura 1 - Variações de retenção foliar, número de raízes e matéria seca de raízes em estacas de Bauhinia x blakeana coletadas na primavera, de acordo com diferentes concentrações de AIB (2009).
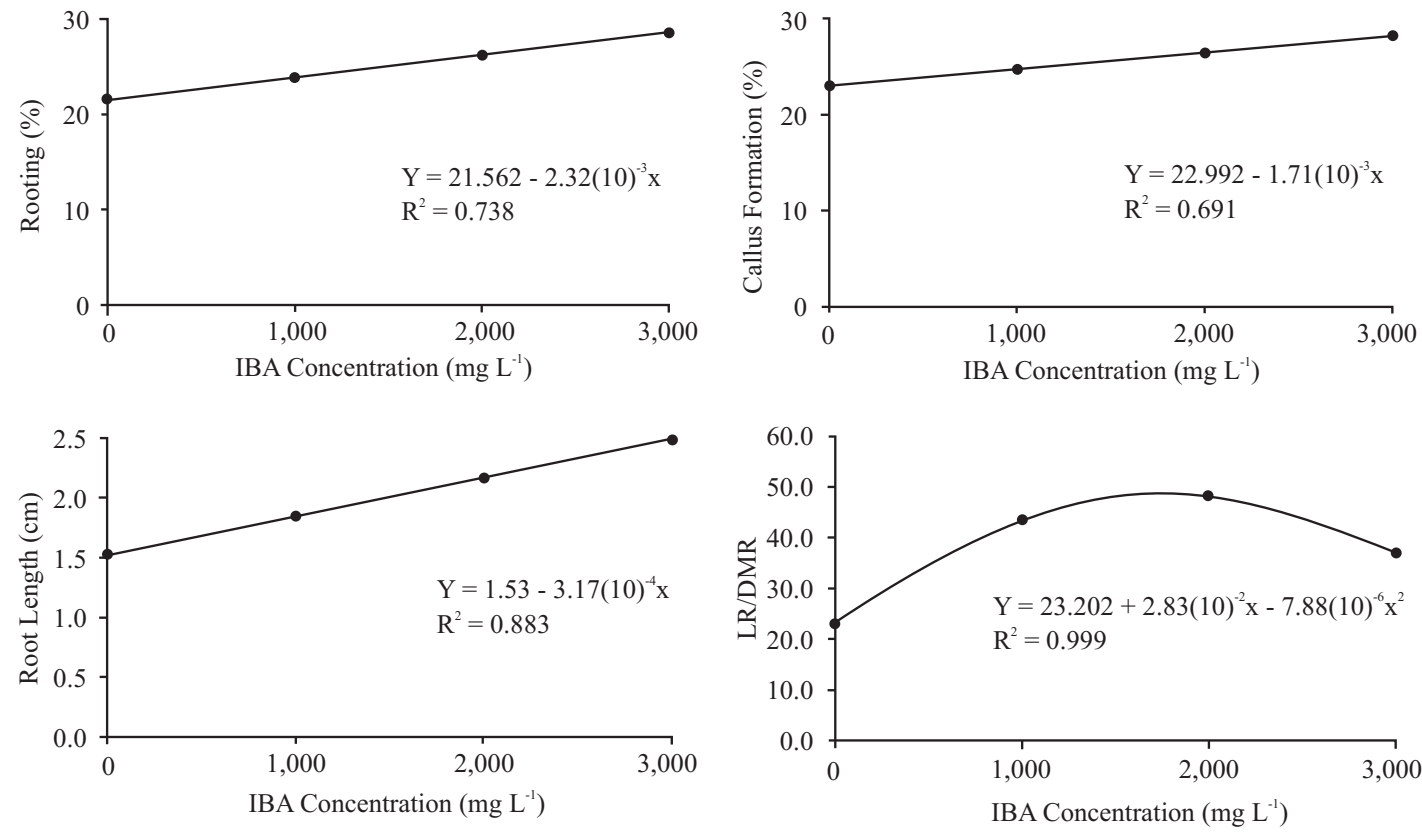

Figure 2 - Variations of rooting, callus formation, root length and the relation of length of roots per dry matter of roots (LR/DMR) of Bauhinia $\mathrm{x}$ blakeana cuttings collected in summer according to different IBA concentrations (2010).

Figura 2 - Variações de enraizamento, formação de calos, comprimento de raízes e relação entre comprimento de raízes e matéria seca de raízes (LR/DMR) em estacas de Bauhinia x blakeana coletadas no verão, de acordo com diferentes concentrações de AIB (2010). 
compounds to keep themselves alive. Furthermore, during the winter, the abscisic acid (ABA) levels in the plant is normally high (NEVES et al., 2006), especially in a deciduous species like $B$. x blakeana. Such phytoregulator inhibits plant growth and, also, works as an auxin antagonist (TAIZ; ZEIGER, 2004), what may have reduced the IBA effects on the cuttings, resulting in high mortality.

Although the environmental conditions influence rooting, each species has its own intrinsic rooting ability. Leafless hardwood cuttings of Ulmus villosa Brandis ex Gamble, for instance, showed better rooting results when collected in the winter, period that precedes its vegetative growth (BHARDWAJ; MISHRA, 2005), just the opposite to what happened to $B$. x blakeana cuttings. In fact, those authors found higher carbohydrate levels in the winter cuttings than in the summer ones. However, $U$. villosa flowers in the spring, what would explain the high nutrient levels found.

Some cuttings collected in the autumn survived and formed calluses, which could differentiate into roots, as it happened with Dalbergia melanoxylon Guill. \& Perr. cuttings (AMRI et al; 2010). For that species, the authors concluded that callus formation did precede root production. However, for $B$. x blakeana cuttings, the survival and callus formation rates were so low that a future trying to propagate it in the autumn, even for a longer period of rooting as suggested by Endres et al. (2007) for Caesalpinia echinata Lam. cuttings, becomes impracticable when considering the rooting success of the spring and summer cuttings.

Cuttings collected in the autumn and winter remained in the rooting bed under the lowest temperatures of the whole experiment. However, the winter temperatures were only slightly lower than the autumn ones, what suggests that the plant physiological status at the collecting time had more influence on the rooting process than the rooting period, as those cuttings that showed a high rooting rate during autumn were actually collected in the summer. Furthermore, low temperatures are not always responsible for the cutting death. Gratieri-Sossella et al. (2008), for instance, concluded that higher temperatures damaged some plant tissues of Erythrina crista-galli $\mathrm{L}$. cuttings.

The significant interaction among the collecting seasons and IBA concentrations for leaf retention, root length and root dry matter indicates that they jointly influenced rooting. The significant difference applied by the collecting seasons for all evaluated variables, except for the NL/DML relation (data not shown), showed that the spring results were better than the summer ones for all those variables, even for the LR/DMR relation, which had a higher value for summer cuttings. In this case, higher values for this variable indicate that the roots had little matter. Therefore, the lower value found for spring cuttings means a more positive result. With regard to the IBA concentrations, there was only a significant difference for leaf retention, root dry matter and the LR/DMR relation, what suggests that such phytoregulator influenced, somehow, the rooting of $B . x$ blakeana cuttings.

As the spring cuttings showed a higher leaf retention rate, it certainly resulted in a major production of photoassimilated compounds, what may have influenced the availability of nutrients for the production of roots and new leaves. As the summer cuttings had a lower leaf retention rate, they produced fewer roots, which were shorter with little matter. According to Shi and Brewbaker (2006), leaf retention is important for both rooting and root growth. In fact, these authors, when working with cuttings of Leucaena Benth. hybrids, also concluded that leaf retention was one of the determining factors for high rooting and root growth. The authors also mentioned that the number of cuttings that prematurely lost their leaves was highly correlated with the number of dead cuttings. Neves et al. (2006) also affirmed that the success on the rooting of Erythrina falcata was reached in part by the maintenance of leaves on the cuttings.

The absence of IBA $\left(0 \mathrm{mg} \mathrm{L}^{-1}\right)$ in B. x blakeana spring cuttings favored the best results of that season (Figure 1). The opposite happened with summer cuttings, as the 3,000 $\mathrm{mg} \mathrm{L}^{-1}$ IBA concentration was distinguished from the others, showing increasing values of rooting, callus formation and root length (Figure 2). This was also verified in the quadratic regression for the LR/ DMR relation (Figure 2), as it indicates that the values of this variable tend to decrease when higher concentrations are applied. When it is related to the root length linear regression, it is possible to infer that, at higher concentrations, there would be roots with more matter.

The answers of the different collecting seasons to the distinct IBA concentrations might denote a range 
on the content of endogenous auxin present in the cuttings (BAULet al., 2011; VALMORBIDA et al., 2008), which varies according to the species, cultivar, cutting type (NEVES et al., 2006) and collecting time. In this case, there might be higher auxin levels in the spring, so that higher IBA concentrations, derived from the exogenous application, negatively influenced root growth and leaf retention. The opposite might have happened in the summer, that is, the exogenous IBA might have complemented the necessary plant endogenous content for growth, what would explain the higher values obtained for the evaluated characteristics under the highest IBA concentration. Furthermore, all endogenous promoter or inhibitor phytoregulators (auxins, gibberellins and cytokinins) must be properly balanced with the available carbohydrates in order to root production take place (AMRI et al., 2010; NEVES et al., 2006).

The ideal IBA concentration, therefore, will rely on the already existent phytoregulator content in the cutting (NICOLOSO et al., 1999). Similar results to this study were found for cuttings of Litsea monopetala (Roxb.) Pers. (BAUL et al., 2011) and Holarrhena pubescens Wall. ex G. Don (BAULet al., 2010), although the collecting time has not been mentioned. In general, though, cuttings that are treated with IBA, regardless its concentration or the collecting time, show better results than those that are not treated (BHARDWAJ; MISHRA, 2005), what did not happened with the $B$. $\mathrm{x}$ blakeana spring cuttings.

\subsection{Grafting}

The results of graft survival found for the first experiment were close to null, what could indicate that the plants were not physiologically ready for such procedure. For this reason, the second grafting experiment was performed with older plants in an attempt to use plants that, maybe, would be more physiologically ready for grafting. However, the results of this second experiment, which was performed one year after germination, also resulted in almost null percentages.

The experiment evaluations did not indicate, though, a possible reason for such low graft survival. Lau et al. (2005) mentioned that the grafting of $B$. x blakeana must be done on same genus species and, indeed, incompatibility signs among species were not observed. Some rootstocks showed a high callus formation on the grafting region, what is necessary for the success of the method (HARTMANN et al., 2002). However, even these plants did not provide satisfactory results.

Although there are studies that testify the importance of different aspects on the grafting success, such as the used method, rootstock and graft origin, rootstock age and environmental conditions (ASSAREH; SARDABI, 2005), the studied factors did not influence the evaluated variables. Furthermore, the collecting time of buds and grafts might have negatively influenced the experiment results. Assareh and Sardabi (2005), for instance, obtained better results on the grafting of Ziziphus spina-christi (L.) Desf. performed in autumn than in spring. The first experiment of this study was carried out in the end of the summer while the second one was done in the end of the winter. Thus, further studies on the collecting time of buds and grafts could be performed in order to endorse the effectiveness or ineffectiveness of the grafting methods for the propagation of $B$. x blakeana.

As it happens with cuttings, each species may respond differently to grafting methods. Unlike to what happened with $B$. x blakeana, some species reach better results when they are propagated by grafting than by cuttings. The Allanblackia floribunda Oliv. species, for instance, had high survival rates when it was grafted on rootstocks of the same species using different grafting methods (ASAAH et al., 2011). In this study, however, both the splice graft and T-budding were not efficient.

\section{CONCLUSIONS}

The Bauhinia $\mathrm{x}$ blakeana hybrid can be propagated by semi-woody cuttings collected in spring, without IBA application, or in summer, with the application of 3,000 $\mathrm{mg} \mathrm{L}^{-1}$ of IBA. Cuttings collected in autumn or winter showed very low survival and rooting rates, regardless the IBA concentration, and were considered impracticable for the multiplication of this species.

The grafting tested methods, splice graft and Tbudding, were not efficient for the propagation of $B$. x blakeana.

\section{ACKNOWLEDGEMENTS}

To the Coordination for the Improvement of Higher Level Personnel (CAPES) for granting a doctorate bursary to the first author; and to the National Council for Scientific and Technological Development (CNPq) for granting a doctorate bursary to the third author.

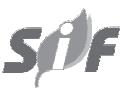

Revista Árvore, Viçosa-MG, v.37, n.2, p.219-229, 2013 


\section{REFERENCES}

ALTHAUS, M. M. et al. Influência do ácido naftaleno acético e dois tipos de substrato no enraizamento de estacas de jasmim-amarelo. Revista Ciência Agronômica, v.38, n.3, p.322-326, 2007.

AMRI, E. et al. Vegetative propagation of African blackwood (Dalbergia melanoxylon Guill. \& Perr.): effects of age of donor plant, IBA treatment and cutting position on rooting ability of stem cuttings. New Forests, v.39, n.2, p.183-194, 2010.

ASAAH, E. et al. Allanblackia floribunda: a new oil tree crop for Africa: amenability to grafting. New Forests, v.41, n.3, p.389-398, 2011.

ASSAREH, M. H.; SARDABI, H.

Macropropagation and micropropagation of Ziziphus spina-christi. Pesquisa

Agropecuária Brasileira, v.40, n.5, p.459465,2005 .

BAUL, T. K. et al. Vegetative propagation of Litsea monopetala, a wild tropical medicinal plant: effects of indole-3-butyric acid (IBA) on stem cuttings. Journal of Forestry

Research, v.22, n.3, p.409-416, 2011.

BAUL, T. K. et al. Vegetative propagation of Holarrhena pubescens, a wild tropical medicinal plant: effect of indole-3-butyric acid (IBA) on stem cuttings. Forestry Studies in China, v.12, n.4, p.228-235, 2010.

BHARDWAJ, D. R.; MISHRA, V. K. Vegetative propagation of Ulmus villosa: effects of plant growth regulators, collection time, type of donor and position of shoot on adventitious root formation in stem cuttings. New Forests, v.29, n.2, p.105-116, 2005.

CARVALHO, A. S.; GRAF, C. C. D.; VIOLANTE, A. R. Produção de material básico e propagação. In: MATTOS JÚNiOR, D. et al. (Ed.) Citros. Campinas: Instituto Agronômico e Fundag, 2005. p.279-316.

ENDRES, L. et al. Enraizamento de estacas de pau-brasil (Caesalpinia echinata Lam.) tratadas com ácido indol butírico e ácido naftaleno acético. Ciência Rural, v.37, n.3, p.886-889, 2007.

Revista Árvore, Viçosa-MG, v.37, n.2, p.219-229, 2013
GRATIERI-SOSSELLA, A.; PETRY, C.; NIENOW, A. A. Propagação da corticeira do banhado (Erythrina crista-galli L.) (Fabaceae) pelo processo de estaquia. Revista Árvore, v.32, n.1, p.163-171, 2008.

HARTMANN, H. T. et al. Plant propagation: principles and practices. 7.ed. Upper Saddle River: Prentice-Hall, 2002. 880p.

LAU, C. P. Y.; RAMSDEN, L.; SAUNDERS, R. M. K. Hybrid origin of "Bauhinia blakeana" (Leguminosae: Caesalpinioideae), inferred using morphological, reproductive, and molecular data American Journal of Botany, v.92, n.3, p.525-533, 2005.

LONE, A. B. et al. Enraizamento de estacas de azaleia (Rhododendron simsii Planch.) no outono em AIB e diferentes substratos. Ciência Rural, v.40, n.8, p.1720-1725, 2010.

LUZ, P. B.; PAIVA, P. D. O.; LANDGRAF, P. R. C. Influência de diferentes tipos de estacas e substratos na propagação assexuada de hortênsia [Hydrangea macrophylla (Thunb.) Ser.]. Ciência e Agrotecnologia, v.31, n.3, p.699-703, 2007.

MAK, C. Y. et al. Molecular evidence for the hybrid origin of Bauhinia blakeana (Caesalpinioideae). Journal of Integrative Plant Biology, v.50, n.1, p.111-118, 2008.

NEVES, T. S. et al. Enraizamento de corticeira-daserra em função do tipo de estaca e variações sazonais. Pesquisa Agropecuária Brasileira, v.41, n.12, p.1699-1705, 2006.

NICOLOSO, F. T.; LAZZARI, M.; FORTUNATO, R. P. Propagação vegetativa de Platanus acerifolia Ait.: (II) Efeito da aplicação de zinco, boro e ácido indolbutírico no enraizamento de estacas.

Ciência Rural, v.29, n.3, p.487-492, 1999.

NOUAIM, R. et al. The argan tree (Argania spinosa) in Morocco: propagation by seeds, cuttings and in-vitro techniques. Agroforestry Systems, v.54, n.1, p.71-81, 2002.

PACHECO, J. P.; FRANCO, E. T. H. Substratos e estacas com e sem folhas no enraizamento de Luehea divaricata Mart. Ciência Rural, v.38, n.7, p.1900-1906, 2008. 
RAIJ, B. van et al. (Ed.) Análise química para avaliação da fertilidade de solos tropicais. Campinas: Instituto Agronômico de Campinas, 2001.284p.

ROBERTO, S. R. et al. Enraizamento de estacas herbáceas dos porta-enxertos de videira 'Campinas' (IAC 766) e 'Jales' (IAC) 572 em diferentes substratos. Ciência Rural, v.34, n.5, p.1633-1636, 2004.
SHI, X.; BREWBAKER, J. L. Vegetative propagation of Leucaena hybrids by cuttings. Agroforestry Systems, v.6, n.1, p.77-83, 2006.

TAIZ, L.; ZEIGER, E. Fisiologia vegetal. 3.ed. Porto Alegre: Artmed, 2004. 719p.

VALMORBIDA, J. et al. Enraizamento de estacas de Trichilia catigua A. Juss. (catigua) em diferentes estações do ano. Revista Árvore, v.32, n.3, p.435-442, 2008. 
